\title{
Precucuteni-type ceramic artefacts from Transylvania (Romania)
}

\section{Mihai GLIGOR}

\section{Abstract}

The aim of this paper is to present the pottery from Alba Iulia-Lumea Nouă (Pl. I-III, IV/2, V/8, VIII, IX/1, 3, X/1-2) and Petreşti-Groapa Galbenă (Pl. IV/1, 3-11, V/1-7, 9, VI-VII, IX/2, 4). The decoration is executed inside the incised parallel lines using the excision technique and consists in the 'wolf's teeth' and 'chessboard'. The excised 'wolf's teeth' and 'chessboard' motifs are typical especially for phase I of Precucuteni culture. In the recent excavations, pottery fired using black-topped technique was discovered, also a fragment from a carinated bowl with rounded carina with 'wolf's teeth' decoration, all typical for the Foeni communities from Transylvania.

Now, the repertory of Transylvanian discoveries comprises no less than 37 archaeological sites with Precucuteni-type pottery (Pl. XI). At the present state of research, we do not believe that all these artefacts can still be interpreted as merely Precucuteni imports in Transylvanian settlements. The lack of habitation levels or archaeological features that we can attribute to the Precucuteni culture, especially in the middle Mureș basin, makes it likely that there was a 'fashion' of decorating pottery among the communities of the early Eneolithic; thus, the typical decoration was taken up following some initial exchanges and contacts. In our opinion, the inclusion of the 'wolf's teeth' and 'chessboard' decoration in the stylistic repertoire of the human communities living in the aforementioned geographic area, constitutes the main explanation of the large number of discoveries of this nature. We believe that especially among the large Neolithic settlements from the middle Mureș basin a significant percentage of the excised pottery had lost its initial ethno-cultural facet. For the moment, from the perspective of the pottery analysed in this paper, a separation between the group of settlements from South-Eastern Transylvania and the sites from South-Western and central Transylvania is taking shape.

Keywords: Alba Iulia-Lumea Nouă, Petrești-Groapa Galbenă, Transylvania, Precucuteni anthropomorphic statuette, 'wolf's teeth' and 'chessboard' excised Precucuteni-type ornamentation, imports / local production.

\section{Introduction}

Our interest in the study of ceramic materials of Precucuteni-type discovered in Transylvania dates back to the publication of the pottery decorated with excisions from Petrești-Groapa Galbenă ${ }^{1}$ and Alba Iulia-Lumea Nouă. ${ }^{2}$ The discovery of

1 Mihai Gligor, „Despre ceramica de tip Precucuteni în Transilvania”. Apulum XLVI (2009): 233-246.

2 Mihai Gligor, Aşezarea neolitică şi eneolitică de la Alba Iulia-Lumea Nouă în lumina noilor cercetări. Cluj-Napoca: Editura Mega, 2009, 91-92. 
new materials in the aforementioned sites, as well as the publication of some recent studies, ${ }^{3}$ presents us with the opportunity to approach once more this research topic, in the wider context of the issue of the Transylvanian Neolithic.

\section{Description of the archaeological material}

Alba Iulia - Lumea Nouă (ALN): Pl. I-III, IV/2, V/8, VIII, IX/1, 3, X/1-2.

One remarkable piece ( $\mathrm{Pl} . \mathrm{X} / 1-2)$ is an anthropomorphic burnt clay female statuette (No. 9191-UAB archaeological collection). Archaeological context: Trench I/2014, Square A, Cx01, $-1.50-1.70 \mathrm{~m}$. The statuette was found in a pit feature, in association with Foeni pottery.

Regarding its appearance, we are dealing with an almost complete anthropomorphic statuette of the female gender. Concerning size, the rondebosse piece can be classified among the small-sized statuettes (between 3 and $8 \mathrm{~cm}$ ) with the bust in a vertical position, according to the typological criteria proposed by D. Monah ${ }^{4}$. S. Marinescu-Bîlcu ascribes them to type $\mathrm{A}^{5}$ (standing statuettes).

The firing was predominantly oxidized; it presents light grey specks in the feet area; it belongs to the fine ceramic category, with good quality, burnished fabric. Dimensions: Height $(\mathrm{H}$ max. $)=77.85 \mathrm{~mm}$; Width $(\mathrm{W} \max )=.24 \mathrm{~mm}$; Thickness in the buttocks area (Thickness max.) $=24.20 \mathrm{~mm}$; Weight $=32.56 \mathrm{~g}$. The proportions of the statuette are as follows: from the base of the crown to the genital area $(32.05 \mathrm{~mm})$; and from the genital area to the end of the inferior limbs $(45.80 \mathrm{~mm})$. Consequently, the inferior limbs represent $60 \%$ of the total height of the statuette.

With respect to the modelling technique, the figurine is made from two separate pieces of clay. This manufacturing process is common to the Precucuteni-Cucuteni phenomena. ${ }^{6}$ One part comprises the entire body and the

3 Gheorghe Lazarovici, Cornelia Magda Lazarovici, „Cultura Precucuteni în Transilvania”. Analele Banatului XXIV, SN (2016): 37-74.

4 Dan Monah, Plastica antropomorfă a culturii Cucuteni-Tripolie. Piatra Neamț, 2012 [Second edition, Bibliotheca Memoriae Antiquitatis, XXVII], 89-92.

5 Silvia Marinescu-Bîlcu, Cultura Precucuteni pe teritoriul României. Bucureşti: Editura Academiei R.S.R., 1974, 90.

6 Marinescu-Bîlcu, Cultura Precucuteni, 93; Ioana Robu, „Date tehnologice privind modelarea statuetelor din complexele de la Isaiia (jud. Iași) și Poduri (jud. Bacău)”, in Dimensiunea europeană a civilizației eneolitice est-carpatice, ed. N. Ursulescu, Iași: Editura Universităţii „Al. I. Cuza”, 2006, 242-243; Monah, Plastica antropomorfă, 78-81; Nicolae Ursulescu, Dumitru Boghian, Vasile Cotiugă, "Contributions to the knowledge of the anthropomorphic plastic art of the Precucuteni culture. The representations from the settlement of Târgu Frumos”, in Anthropomorphism and symbolic behaviour in the Neolithic and Copper Age communities of SouthEastern Europe, Eds. C. E. Ursu and S. Țerna, Suceava: Editura Karl A. Romstorfer, 2014, 382; 
left leg, whilst the other one, the right leg, is thicker and longer than the left. The break occurred in the area where the legs were joined together, from the hips until to bellow the breasts. The statuette was not decorated in any way, neither incised nor painted. The small, round breasts were applied almost symmetrically. The short, thick neck starts from the base of the shoulders. The nose was pulled from the soft clay, a procedure which allowed the sketching of the eyes, these being the only modelled elements composing the face. Both arms were broken above the elbow since ancient times; thus, we know for sure they were not lining the body. The hips and buttocks are very well developed, so we can say that a prominent, almost pointed butt was modelled. A moderate steatopygia is, therefore, to be seen in the manufacturing canon of the statuette from Lumea Nouă.

The anthropomorphic plastic art discovered, so far, at Lumea Nouă is assigned to the Vinča, ${ }^{7}$ Foeni $^{8}$ and Petrești ${ }^{9}$ cultures. Given the technique and modelling criterion, the statuette analysed in the present paper most likely represents an imported piece from the Precucuteni area. Only a scarce number of anthropomorphic female figurines attributed to the Precucuteni culture are known from Transylvania, namely those from Olteni ${ }^{10}$ (Covasna County). One of the statuettes from Olteni-Cariera de Nisip/Site B, ${ }^{11}$ another from Leánykavár ${ }^{12}$ spot (Ariușd cultural group), as well as a Precucuteni I anthropomorphic figurine from Traian-Dealul Viei ${ }^{13}$, have their butts modelled with laterally faceted buttocks, which are very similar to our statuette. Concerning the modelling of the anatomical features of the face, we find analogies in the Ariușd statuettes from the eponymous site, ${ }^{14}$ in a Precucuteni II statuette from Larga Jijia, ${ }^{15}$ and from

Gheorghe Dumitroaia and Constantin Emil Ursu, "The Anthropomorphic Representations from the Cucuteni site at Căşăria-Dealul Mătăhuia (Dobreni, Neamț County)”, in Anthropomorphism and symbolic behaviour in the Neolithic and Copper Age communities of South-Eastern Europe, Eds. C. E. Ursu and S. Țerna, Suceava: Editura Karl A. Romstorfer, 2014, 435-438, Fig. 4/3-5.

7 Mihai Gligor, „Plastica antropomorfă neolitică din Transilvania. Tradiţie şi inovaţie”. Annales Universitatis Apulensis, Series Historica 17, II (2013): Pl. I/1-5.

8 Gligor, „Plastica antropomorfă”, Pl. II/1-5.

9 Gligor, Aşezarea, Pl. CLI/5.

${ }^{10}$ Daniel Garvăn, Dan Buzea, Alin Frînculeasa, Precucuteni. Originea unei mari civilizații, PiatraNeamț, 2009 [Bibliotheca Memoriae Antiquitatis XIII], 68/Fig. 35-37; Lazarovici and Lazarovici, „Cultura Precucuteni”, 64-65, Fig. 28/1-4.

${ }^{11}$ Lazarovici and Lazarovici, „Cultura Precucuteni”, Fig. 28/1.

${ }^{12}$ Sándor József Sztáncsuj, Grupul cultural Ariuşd pe teritoriul Transilvaniei. Cluj-Napoca: Editura Mega, 2015, Pl. CCXX/10.

${ }^{13}$ Marinescu-Bîlcu, Cultura Precucuteni, 92, Fig. 71/14.

${ }^{14}$ Sztáncsuj, Grupul cultural Ariuşd, Pl. CCXVII/1, CCXXIV/3.

${ }^{15}$ Marinescu-Bîlcu, Cultura Precucuteni, Fig. 72/7. 
a Cucuteni A figurine from Hăbășești. ${ }^{16}$ The anthropomorphic female figurines dated to the developed and final phases of the Precucuteni culture, known from the archaeological features at Poduri ${ }^{17}$ and Isaiia, ${ }^{18}$ present us with a picture of the evolution of modelling and decoration rules in the East Carpathian territory.

In the excavations from 1976 (Pl. I/2, 6; Pl. II/1, 5, 10), ${ }^{19} 2005-2008$ (Pl. I/1, 3-4; Pl. II/2-4, 7-9, 11; Pl. III/4, 7) ${ }^{20}$ and 2011-2015 (Pl. I/5; Pl. II/6; $\mathrm{Pl}$. III/1-6, 8-10; IV/2; V/8) ${ }^{21}$ ceramic fragments presenting characteristic decorations of the excised Precucuteni-type ornamentation were found at Alba Iulia-Lumea Nouă.

The decoration is executed inside the incised parallel lines using the excision technique and consists in the 'wolf's teeth' (Pl. I/1-5; Pl. II/3-5, 9-10; Pl. III/1-3, 6-9) and 'chessboard' (Pl. II/1-2, 7) motifs. Both the triangles and the squares are sometimes arranged in bands, each composed of two alternating rows bordered by incised lines. Within the decoration of the same ceramic fragment we encounter a combination of the 'wolf's teeth' and 'chessboard' motifs (Pl. I/6; Pl. II/6; Pl. III/5). For the fragmented pottery pieces from Lumea Noua, the following shapes can be distinguished: bottoms (Pl. I/6; Pl. II/9-11; Pl. $\mathrm{V} / 8$ ), rims (Pl. II/6; Pl. III/1, 5, 7, 9-10), the neck of some amphorae (Pl. I/3; $\mathrm{Pl}$. II/8; Pl. III/3). An important piece is a fragment from a carinated bowl with rounded carina $\left(\mathrm{Pl}\right.$. III/9 $=\mathrm{Pl}$. VIII/6), typical for the Foeni group. ${ }^{22}$ The brick red - greyish pottery of the semi-fine category is predominant (Pl. I/1-2, 4-6; Pl. II/1, 3-7, 9-11; Pl. III/2-6, 8, 10; Pl. IV/8; Pl. V/2; Pl. VIII/3-4).

Artefacts, such as those illustrated in Pl. I/3 (Pl. IX/1), Pl. II/2, Pl. II/8 (Pl. IX/3), Pl. III/9 (Pl. VIII/6) are made from a fabric and are fired and burnished

${ }^{16}$ Vladimir Dumitrescu, Arta neolitică în România. Bucureşti: Editura Meridiane, 1979, 75, Fig. 60/a.

${ }^{17}$ Dan Monah, Gheorghe Dumitroaia, Felicia Monah, Constantin Preoteasa, Roxana Munteanu, Dorin Nicola, Poduri-Dealul Ghindaru. O Troie în Subcarpații Moldovei, Piatra-Neamţ, 2003 [Bibliotheca Memoriae Antiquitatis XIII], 107-111, 143-145, 160-161.

${ }^{18}$ Nicolae Ursulescu, Felix Tencariu, Religie şi magie la est de Carpaţi. Tezaurul cu obiecte de cult de la Isaiia. Iaşi: Editura Demiurg, 2006, 82-119.

${ }^{19}$ Gligor, Aşezarea, 91, 208; Pl. CXLVIII/1, 5-6, CXLIX/2, 4.

${ }^{20}$ Gligor, Aşezarea, 91, 208; Pl. CXLVIII/2-4, 7-12, CXLIX/3, 5-6.

${ }^{21}$ Archaeological context: Pl.I/5=Trench I/2015, square A, $-0.85-1.05 \mathrm{~m}$; Pl.II/6(VIII/4)=Trench II/2015, square B, -1.00-1.15m; Pl. III/1 = Trench III/2014, square B, -0.80-1.00m; Pl. III/2=Trench II/2014, square B, -0.20-0.40m; Pl. III/3=Trench III/2014, square D, -1.10$1.30 \mathrm{~m}$; Pl. III $/ 5=$ Trench II/2015, square C, $-0.75-0.80 \mathrm{~m}$; Pl. III/6=Trench I/2015, square A, -1.05-1.30m; Pl. III/8=Trench II/2015, square D, -1.20-1.40m; Pl. III/9=Trench II/2014, square $B,-0,30-0,60 \mathrm{~m}$; Pl. III/10=Trench III/2014, square A, -1.10-1.35m; Pl. V/8=Trench I/2011, square D, Cx02, -1,50-1,70m.

${ }^{22}$ Gligor, Aşezarea, 75-76, Pl. CXVII/7-10, 12, Pl. CXXXVI-CXXXVIII. 
in a way, typical for the Foeni group. This is a fine, intensively burnished pottery, having a dark grey, almost black colour. Furthermore, recent excavations have uncovered ceramic pieces fired using the black-topped technique Pl. VIII/1 (Pl. III/10), VIII/2 (Pl. III/1), which is typical for the Foeni communities at Lumea Nouă. ${ }^{23}$

Petrești-Groapa Galbenă (PGG): Pl. IV/1, 3-11, V/1-7, 9, VI-VII, IX/2, 4.

The ceramic materials from the Raica and Haldenwang collection (Pl. VI/14; VII/1-6), ${ }^{24}$ which originate from the Petrești site (Alba county), are stored by the National Museum of Unification in Alba Iulia. For the present study, the materials yielded by the rescue excavation carried out in the year $2011^{25}$ ( $\mathrm{Pl}$. IV/1, 3-11; V/1-7, 9) ${ }^{26}$ should also be added.

The brick red - greyish, semi-fine pottery predominates (Pl. IV/1, 3-4, 6-10; $\mathrm{Pl}$. V/1-3, 6-7; Pl. VI/2; Pl. VII/1-2, 6). One ceramic fragment (Pl. IV/5) comes from a yellow-orange coloured, well-burnished vessel belonging to the fine ware category. Among the black, very well-burnished, metallic-like pottery, we include the pieces illustrated in Pl. IV/11 (Pl. VIII/6) and Pl. V/9 (Pl. IX/4). In case of other vessels, also black (Pl. V/4, VII/3-5), we notice that they had lost their burnish. Their walls are, nevertheless, thin and resonant. The vessel bottoms (Pl. $\mathrm{VI} / 1,4$ ) have a yellowish-reddish orange colour on the exterior side, while on the interior they are coloured in black. This circumstance is specific to controlled, mixed firing, in an oxidizing and reducing atmosphere, which produces the chromatic black-topped effect. Furthermore, in the 2011 excavation, pottery fired using the black-topped technique was discovered (Pl. V/5), typical for the Foeni communities from Transylvania.

For the pottery from Petrești, found in a fragmentary state, we can note the following with respect to shape: biconical bowl (Pl. IV/11, V/1, 5, 9; VI/2, VII/6), bowl in the shape of a truncated cone (Pl. VII/5), bottoms (Pl. IV/910; VI/1, 4), rims (Pl. VII/1-2), the neck of an amphora (Pl. IV/6; VII/3). The vessel illustrated in $\mathrm{Pl}$. VII/5 has a lobe on its rim, but the fragmentary condition does not allow us to determine whether or not it was a quadri-lobed bowl. The biconical bowls with contoured shoulder and rounded rim illustrated

${ }^{23}$ Gligor, Aşezarea, 72.

${ }^{24}$ Gligor, „Despre ceramica”, 233, footnote 2; Pl. I/1-2, Pl. II/1-3, Pl. III/1-5.

${ }^{25}$ Mihai Gligor, Mariana Roșu, Călin Şuteu, "New Evidence on Burial Practices in Petrești Culture”. Materiale şi Cercetări Arheologice (SN) IX (2013): 67-68, Pl. I; Gligor, „Plastica antropomorfă”, 77-78, Pl. II/6a-6d.

${ }^{26}$ Archaeological context: Pl. IV/1, 4=square D, context 031; Pl. IV/3, 10, Pl. V/7= square $\mathrm{D}$, context 037 ; Pl. IV $/ 5=$ square $\mathrm{B}$, context 039 ; Pl. IV/6= square $\mathrm{B}$, context 023 ; Pl. IV/79=Trench 1, Cx017; Pl. IV/11=square D, context 028; Pl. V/1, 4=square B, context 041; Pl. $\mathrm{V} / 2$ = square $\mathrm{A}$, context $029 ; \mathrm{Pl}$. V/3=square $\mathrm{B}$, context $022 ; \mathrm{Pl} . \mathrm{V} / 5,9=$ square $\mathrm{D}$, context 021 . 
in $\mathrm{Pl}$. V/5, VII/4 can be seen in variant $\mathrm{B} 4 \mathrm{~b}^{27}$ of the shape catalogue belonging to the Foeni group. The decoration is executed incised, parallel lines, using the excision technique of the 'wolf's teeth' (Pl. IV/1, 4-5, 7-11; V/2-4, 6-7; VI/3$4 ; \mathrm{VII} / 1,4)$ and 'chessboard' (Pl. IV/6, VII/6) motifs. Sometimes the triangles composing the 'wolf's teeth' motif and the chessboard squares are arranged in bands, consisting of alternating rows, framed by incised lines. Both of the aforementioned decorative motifs can be combined on the same ceramic vessel (Pl. VI/1-2; VII/2-3, 5). The practice of decorating the vessel bottom with excised 'wolf's teeth' pattern (Pl. VI/1, 4) is rarely encountered on Precucuteni pottery. ${ }^{28}$ The vessel bottom illustrated in Pl. VI/4 still preserves traces of the white inlay inside the 'wolf's teeth'.

\section{Discussions}

The excised 'wolf's teeth' and 'chessboard' motifs are typical, especially for phase I of Precucuteni - as defined when the monograph of the culture was publishedbased on the discoveries from Traian-Dealul Viei. ${ }^{29}$ In phase II of the Precucuteni culture, the decoration technique employing the excised aforementioned motifs is continued from the previous stage - as evidenced by the material from Ghigoești-Trudești ${ }^{30}$ and Larga-Jijia ${ }^{31}$ - but gradually declines, becoming simple notches. ${ }^{32}$ This observation is illustrated by the pottery fragments seen in $\mathrm{Pl}$. II/4, 8-11, Pl. III/4, 10, Pl. IV/2- 3; V/1, 5, 8; VI/1; VII/6.

Regarding the decoration, for the lot of pottery fragments from Alba IuliaLumea Nouă and Petrești-Groapa Galbenă, we identified numerous analogies, both in material originating from Transylvania (Bancu, ${ }^{33}$ Cașolț-Poiana în Pisc, ${ }^{34}$ Cerișor-Peștera Cauce, ${ }^{35}$ Ciucsângeorgiu, ${ }^{36}$ Daia Română-Părăuț, ${ }^{37}$ Ghirbom, ${ }^{38}$

${ }^{27}$ Florin Drașovean, “Die Petrești-Kultur im Banat”. Praehistorische Zeitschrift 72 (1997): Abb. 2.

${ }^{28}$ Marinescu-Bîlcu, Cultura Precucuteni, 62.

${ }^{29}$ Marinescu-Bîlcu, Cultura Precucuteni, 55-63; Fig. 26/1-3, 8, 27/1-6, 28/1-2, 4, 29/2-4, 30/1-2, $32 / 1-8,33 / 1-3,34 / 2-5,7,9-10,35 / 1-4,36 / 1-8,37 / 1-14$.

${ }^{30}$ Marinescu-Bîlcu, Cultura Precucuteni, Fig. 44/2, 12, 52/5, 14.

${ }^{31}$ A. D. Alexandrescu, “O vtoroi faze Docucutenscoi culturî”. Dacia, N. S., V (1961): Pl. IV/6-7, 16, 21-22, V/1, 4-5, 10-11; Marinescu-Bîlcu, Cultura Precucuteni, Fig. 52/9, 12-13, 15.

${ }^{32}$ Marinescu-Bîlcu, Cultura Precucuteni, 67.

${ }_{33}^{3}$ Marinescu-Bîlcu, Cultura Precucuteni, fig. 29/1.

${ }^{34}$ Iuliu Paul, „Aşezarea neolitică târzie de la Poiana în Pisc”. Materiale şi Cercetări Arheologice VII, 1 (1961): Fig. 6/9.

${ }^{35}$ Sabin Adrian Luca, Cristian Roman, Dragoş Diaconescu. Cercetări arheologice în peştera Cauce (I), Sibiu, 2004 [Bibliotheca Septemcastrensis, IV], Pl. XXXV/1, Photo 28/2-6.

${ }^{36}$ Valeriu Cavruc Ed., Repertoriul arheologic al județului Harghita. Sfântu Gheorghe: 2000, Pl. 5/1.

${ }^{37}$ Iuliu Paul, Cultura Petreşti. Bucureşti: Editura Museion, 1992, Pl. XXII/3-4, 6, 9.

${ }^{38}$ Paul, Cultura, Pl. XXII/13. 
Goreni-Tormaș, ${ }^{39}$ Mintia-Gerhat, ${ }^{40}$ Oarda-Dublihan, ${ }^{41}$ Ocna Sibiului, ${ }^{42}$ OlteniCariera de Nisip/Site B, ${ }^{43}$ Pianu de Jos-Podei, ${ }^{44}$ Turdaș, ${ }^{45}$ T,aga, ${ }^{46}$ Valea NandruluiDosul Mare ${ }^{47}$ ), and from Moldova (Ghigoești-Trudești, ${ }^{48}$ Larga Jijia, ${ }^{49}$ Târpești, ${ }^{50}$ Traian-Dealul Viei ${ }^{51}$ ).

When writing the monograph dedicated to the Precucuteni culture, S. Marinescu-Bîlcu ${ }^{52}$ proposed the hypothesis that the final Precucuten I communities advanced towards Central Transylvania, where they were assimilated by the Turdaș culture and lost their identity. The lack of Precucuteni III material from sites located inside the Carpathian arch supports this theory

${ }^{39}$ Andrei Zrínyi, „Contribuții la cunoaşterea neoliticului din valea superioară a Mureşului: săpăturile de la Goreni”. Marisia XI-XII (1981-1982): Pl. I/8, VII/6.

${ }^{40}$ Florin Draşovean, Sabin Adrian Luca, „Considerații preliminare asupra materialelor neoeneolitice din aşezarea de la Mintia”. Studii şi Cercetări de Istorie Veche şi Arheologie 41, 1 (1990): Fig. 4/3.

${ }^{41}$ Gabriel Rustoiu, „Aşezarea de la Oarda-Dublihan (mun. Alba Iulia)”. Patrimonium Apulense I (2001): Pl. II/2.

${ }^{42}$ Paul, Cultura, Pl. XXII/10.

${ }^{43}$ Dan Buzea, Adela Mateș, „Modele miniaturale de altare descoperite la Olteni - „Cariera de nisip”, Situl B, jud. Covasna. Angustia 12 (2008): 42, Pl. III/2; Garvăn et alii, Precucuteni, 70/Fig. 41; Dan Buzea, Andreea (Chiricescu) Déak, "Ethno-Archaeological Discoveries from Olteni, Covasna County, Romania”, in Facets of the past. The challenge of the Balkan Neo-Eneolithic, (Eds.) A. Comşa, C. Bonsall, L. Nikolova, Bucureşti: Editura Academiei Române, 2013, 613, Fig 5/4-5.

${ }^{44}$ Iuliu Paul, „Așezarea neo-eneolitică de la Pianul de Jos (Podei), jud. Alba”. Studii și Comunicări Muzeul Brukenthal Istorie 14 (1969), Pl. III/9-10, 16-18; Cătălin Bem, Sistemul de fortificare al staţiunii eneolitice de la Pianu de Jos-Podei (Alba, România). Între simbolism și rațiuni defensive. Târgoviște, Editura Cetatea de Scaun 2015 [Muzeul Naţional de Istorie a României, Monografii X], Fig. 97/2.

${ }^{45}$ Sabin Adrian Luca, „Relațiile culturale de la sfârșitul neoliticului dezvoltat dintre Transilvania și ținuturile înconjurătoare”. Cultură și civilizație la Dunărea de Jos XV (1997): Pl. I/5, II/1; Sabin Adrian Luca, Așezări neolitice pe Valea Mureșului (II). Noi cercetări arheologice la Turdaș-Luncă. I. Campaniile anilor 1992-1995. Bucureşti, Editura Economică [Bibliotheca Musei Apulensis, XVII], Fig. 36/5; Sorin Colesniuc, Cultura Zau. Constanța: Editura Ex Ponto, 2014, Fig. 160.

${ }^{46}$ Cornelia Magda Lazarovici, Gheorghe Lazarovici, Arhitectura neoliticului și epocii cuprului din România. (I) Neoliticul. Iași: Editura Trinitas, 2006, Fig. IVd. 27.

${ }^{47}$ Sabin Adrian Luca, Cristian Roman, „Cercetări de suprafață în așezarea neolitică de la Valea Nandrului-La dos". Corviniana V (1999): Pl. XVII/7.

${ }^{48}$ Marinescu-Bîlcu, Cultura Precucuteni, Fig. 52/16.

${ }^{49}$ Marinescu-Bîlcu, Cultura Precucuteni, Fig. 52/13, 15-16; Alexandrescu, „O vtoroi faze”, Pl. $\mathrm{IV} / 21, \mathrm{~V} / 4$.

${ }^{50}$ Marinescu-Bîlcu, Cultura Precucuteni, Fig. 52/12.

${ }^{51}$ Marinescu-Bîlcu, Cultura Precucuteni, Fig. 32/6, 8, fig. 37/2-3, 7, 9, 14; Garvăn et alii, Precucuteni, 73/Fig. 52.

${ }^{52}$ Marinescu-Bîlcu, Cultura Precucuteni, 134. 
as well. By studying the material with Precucuteni decoration from sites such as Cașolț-Poiana in Pisc or Câlnic, I. Paul ${ }^{53}$ also noticed that the fabric was typical for the levels with Petrești pottery. Regarding the excised pottery from the intraCarpathian region, E. Comșa ${ }^{54}$ stated that its occurrence in small amounts, in closed archaeological features, is characteristic and that it was manufactured from an atypical fabric, with some examples even made from a technique specific to the Petrești culture. Based on the Precucuteni discoveries from Turdaș, features of the eponymous site, S. A. Luca ${ }^{55}$ held the opinion that the ceramic artefacts regarded as imports can be part of the stylistic repertoire of the Turdaș pottery. The recently published fragment decorated with 'wolf's teeth' from Turdaș ${ }^{56}$ belongs to the category of black burnished pottery, typical for the Foeni group.

A comprehensive and documented synthesis study on the Precucuteni culture from Transylvania was recently published by Gh. and M. Lazarovici. The main conclusion it reaches is that, at the present state of research, there is no Precucuteni culture in Transylvania, only Precucuteni imports (seen as results of exogamous marriages, market places and goods exchanges involving vessels); regarding the possibility of local imitations of Precucuteni pottery, the cited authors reject this hypothesis. ${ }^{57}$

By analysing the most frequent Precucuteni decoration applied on the pottery discovered from Transylvanian sites numbered by the aforementioned authors, ${ }^{58}$ we notice that 15 out of the 20 decorative patterns registered include the excised 'wolf's teeth' and 'chessboard'.

Studying this type of pottery, we can see that, within the decoration repertoire specific to phases I and II of Precucuteni culture, ${ }^{59}$ the most frequently encountered motifs on artefacts coming from Transylvanian sites are the excised 'wolf's teeth' and 'chessboard'. At the same time, we remark that the incised apexes decoration, frequent on Precucuteni I pottery from Traian-Dealul Viei ${ }^{60}$

${ }^{53}$ Paul, Cultura, 54.

${ }^{54}$ Eugen Comşa, „Cultura Boian în Transilvania”. Studii şi Comunicări de Istorie Veche 16, 4 (1965), 631; Eugen Comşa, Istoria comunităților culturii Boian. Bucureşti: Editura Academiei RSR, 1974, 242-243.

${ }^{55}$ Sabin Adrian Luca, „Aspecte ale neoliticului şi eneoliticului din sudul şi sud-vestul Transilvaniei”. Apulum XXXVI (1999): 13; Sabin Adrian Luca, "The Neolitihic and Eneolithic Period in Transylvania”, The Danube Script: Neo-Eneolithic Writing in Southeastern Europe, Ed. J. Marler, Sebastopol, 2008, 31.

${ }^{56}$ Colesniuc, Cultura Zau, Fig. 160/right.

${ }^{57}$ Lazarovici and Lazarovici, „Cultura Precucuteni”, 37-65.

${ }^{58}$ Lazarovici and Lazarovici, „Cultura Precucuteni”, Fig. 4.

${ }^{59}$ Marinescu-Bîlcu, Cultura Precucuteni, 55-63.

${ }^{60}$ Marinescu-Bîlcu, Cultura Precucuteni, Fig. 28/1a-1b, 30/1a, 32/3, 7, 33/2-3, 36/2, 4, 7, 37/1, 13. 
or Baia-În Muchie, ${ }^{61}$ also present on pottery from South-East Transylvania (Sf. Gheorghe $^{62}$ and Olteni ${ }^{63}$ ), can no longer be found in the ornamentation of the pottery discovered in settlements from the middle Mureş basin and central Transylvania.

The Precucuteni I material from sites such as Eresteghin, Ciucsângiorgiu or Turia are considered different and of a better quality compared to the pottery pertaining to this stage in Moldova, a fact that points to the possibility of identifying the genesis of Precucuteni also in South-Eastern Transylvania, ${ }^{64}$ confirming the opinion of S. M. Bâlcu, who included South-Eastern Transylvania in the area of the birth of Precucuteni culture. N. Ursulescu ${ }^{65}$ also stated that the formation of the Precucuteni culture took place on both sides of the southern and central groups of the Eastern Carpathian Mountains.

The nature of the relations between the Boian - Giulești and Precucuteni communities in sites from South-Eastern Transylvania is yet unclear. A series of discoveries from this area ${ }^{66}$ are also assigned to Boian - Giuleşti-type communities. ${ }^{67}$ The pottery with excised decoration belonging to the Boian culture, Giuleşti phase, also included the specific 'wolf's teeth' ${ }^{68}$ or 'chessboard'69

${ }^{61}$ Constantin Emil Ursu, Constantin Aparaschivei, "A Few considerations on some of the ceramic vessels decorated with stylized anthropomorphic representations, from Precucuteni-Tripolye A area”. Brukenthal. Acta Mvsei IX, 1 (2014): 20-22, 27-30, 32-34, 37; Constantin Emil Ursu, Stanislav Țerna, "Tracing the megastructures back in time: an exceptional building from the settlement Baia - În Muchie, Suceava county, Romania”, in At the Eastern frontiers of Old Europe. Kirovograd, 2015, 49-50, fig. 4.

${ }^{62}$ Marinescu-Bîlcu, Cultura Precucuteni, Fig. 31/3-4.

${ }^{63}$ Garvăn et alii, Precucuteni, 72/Fig. 48.

${ }^{64}$ Gheorghe Lazarovici, „Din istoria străveche a Carpaţilor Orientali”. Angustia 1 (1996), 33-34; Zoia Maxim, Neo-eneoliticul din Transilvania. Cluj-Napoca, 1999 [Bibliotheca Musei Napocensis, XIX], 98-99; Valeriu Cavruc, Dan Buzea, „Olteni, com. Bodoc, jud. Covasna. Punct: Cariera de nisip/tag, situl B”. Cronica Cercetărilor Arheologice, 2007, 249; Buzea and Mateş, „Modele miniaturale", 44.

${ }^{65}$ Nicolae Ursulescu, Începuturile istoriei pe teritoriul României. Iaşi: Casa Editorială Demiurg, 2002, 111.

${ }^{66}$ Marinescu-Bîlcu, Cultura Precucuteni, 127, 132; Comşa, Istoria comunităților, Pl. 16/2, 5.

${ }^{67}$ Comşa, Istoria comunităților, 32-36, Fig. 10; Marian Neagu, Neoliticul mijlociu la Dunărea de Jos, Călăraşi, Editura Daim, 2003 [Cultură şi civilizație la Dunărea de Jos, XX], 219, Pl. XXXVIII; Ioniță et alii Adrian Ioniță, Dan Căpățână, Nikolaus Boroffka, Rodica Boroffka, Adrian Popescu, Feldioara-Marienburg. Contribuții arheologice la istoria Țării Bârsei. București : Editura Academiei Române, 2004, 16-17; Lazarovici and Lazarovici, „Cultura Precucuteni”, 49-50, Fig. 5-9.

${ }^{68}$ Comşa, Istoria comunităților, Pl. 7/1, Pl. 8/2-3, Pl. 9/1, 3, 14-16, Pl. 13/1-4, 8, 10, 17; Neagu, Neoliticul mijlociu, Pl. XLIII/2-5, XLIV/1-2, XLVII/1, 5, XLVIII/1-3, XLIX/2-3, L/1, LI/1, LII/1-3; LXXIV/1-2, LXXV/1-2.

${ }^{69}$ Comşa, Istoria comunităților, Pl. 8/12, Pl. 9/5-6, 11, Pl. 13/1, 5-6, 15; Neagu, Neoliticul mijlociu, XLVIII/3-5, XLIX/1, LI/1. 
patterns. For instance, it was noted that at Feldioara, a Boian-Giulești level was distinguished, a level which was superimposed by another containing Precucuteni I and Boian-Vidra material. ${ }^{70}$ More recent excavations at Feldioara highlighted the fact that prehistoric materials are mixed in medieval and modern layers, ${ }^{71}$ meaning that the stratigraphy known from the specialised literature must be treated with caution. On the basis of typological and stylistic criteria, the authors of the new research attributed a lot of archaeological material to the Boian culture. ${ }^{72} \mathrm{~A}$ similar conclusion is also reached by Gh. Lazarovici. ${ }^{73}$

Apart from the dissimilarities resulting from the choice of temper, manufacture, smoothing and firing, the mode of arranging the excised decoration and the association with other motifs on the same ceramic vessel represent, in our opinion, the differences that allow one to attribute the material either to the Precucuteni, or to the Boian cultures.

The chronology of the Precucuteni-type material from Alba Iulia-Lumea Nouă and Petrești-Groapa Galbenă is connected to the Foeni habitation ${ }^{74}$. Thus, the archaeological data known from more recent discoveries, such as those from Cauce, ${ }^{75}$ is confirmed. The vessel lid from Cerişor-Peştera Cauce -decorated in the 'wolf's teeth' and 'chessboard' technique, with white inlay ${ }^{76}$ - was discovered in the upper part of the Turdaş layer, alongside a bowl ${ }^{77}$ fired in the black-topped technique, with burnished decoration inside, belonging to the Foeni group. Starting from the very good analogies with pieces from Traian-Dealul Viei and Olteni, it is argued that the Cauce piece is an import. ${ }^{78}$ Similarly, in the Foeni site recently researched at Pianul de Jos-Podei, the author of the discovery of a vessel excised in the 'wolf's teeth' technique assigns it to Precucuteni . $^{79}$

The C14 analyses on the Precucuteni settlement from Poduri-Dealul Ghindaru $^{80}$ indicate the date as being $5820 \pm 50$ BP (Bln-2804) for the

${ }^{70}$ Lazarovici, „Din istoria”, 33.

${ }^{71}$ Ioniță et alii, Feldioara-Marienburg, 12-13.

${ }^{72}$ Ioniţă et alii, Feldioara-Marienburg, 16-17, Fig. 7/2, 4, 101-11, Fig. 8/1-3, 6; Fig. 10/1, 3-7, Fig. 11.

${ }^{73}$ Lazarovici and Lazarovici, „Cultura Precucuteni”, Fig. 24c.

${ }^{74}$ Mihai Gligor, „Cu privire la locuirea neolitică de la Petreşti-Groapa Galbenă”. Apulum XLV, (2008): 309-311, Pl. V-VII, IX-XII; Gligor, Aşezarea, 71-86, Pl. XLV-CXLI, CXLVIII; 2013, 77 78, Pl. II/6a-6d.

${ }^{75}$ Luca et alii, Cercetări arheologice, 89-90.

${ }^{76}$ Luca et alii, Cercetări arheologice, $\mathrm{Pl}$. XXXV/1.

${ }^{77}$ Luca et alii, Cercetări arheologice, Pl. XXX/2a-2b, Photo 29-30.

${ }^{78}$ Lazarovici and Lazarovici, „Cultura Precucuteni”, 51.

${ }^{79}$ Bem, Sistemul, 32, Fig. 97, 108, 112, 120, 124, 127/1-2, 6, 10.

${ }^{80}$ Cornelia Magda Mantu, „Cronologia absolută a culturilor neolitice din România şi relaţiile cu lumea egeo-anatoliană”. Cercetări istorice XVII, 1 (1998): 99; Tab. 1; Monah et alii, Poduri-Dealul Ghindaru, 63. 
Precucuteni II phase, meaning 4780-4619 calBC $(1 \sigma)$, whereas for $(2 \sigma)$ the interval is $4836-4548 \mathrm{calBC}$. The comparative study of the radiocarbon data known for the Precucuteni culture in Moldova with the C14 data from Foeni sites in Transylvania containing Precucuteni material presents us with the following situation: for Alba Iulia-Lumea Nouă ${ }^{81}$ we have the date $5700 \pm 50 \mathrm{BP}$ (Poz-19451), obtained from a sample extracted from a Foeni pit house (46004460 calBC $(1 \sigma)$, while for $(2 \sigma)$ the interval is $4690-4440$ calBC; for Pianul de Jos-Podei there are four radiocarbon dates obtained from human remains (Start - mean 4650 BC, End - mean 4589 BC). ${ }^{82}$ For the Petrești culture (A-B phase) from the eponymous site, ${ }^{83}$ the date given was $5580 \pm 35 \mathrm{BP}$ (Poz-58216), meaning $4449-4369$ calBC $(1 \sigma)$, while for $(2 \sigma)$ the interval is $4465-4348$ calBC.

\section{The repertory of Precucuteni discoveries in Transylvania}

At the present moment, the repertoire of Transylvanian discoveries comprises no less than 37 archaeological sites: Alba Iulia-Lumea Nouă, ${ }^{84} \mathrm{Bancu}^{85}$ Bernadea, ${ }^{86}$ Brăduț, ${ }^{87}$ Bogatu Român, ${ }^{88}$ Caşolț-Poiana în Pisc, ${ }^{89}$ Câlnic, ${ }^{90}$ CerişorPeştera Cauce, ${ }^{91}$ Ciucsângeorgiu, ${ }^{92}$ Daia Română - Părăuţ, ${ }^{93}$ Deva - Tăualaş, ${ }^{94}$

${ }^{81}$ Gligor, Aşezarea, 141, Pl. CLXXIX/3.

${ }^{82}$ Bem, Sistemul, 107-111.

${ }^{83}$ Mihai Gligor, „Începuturile eneoliticului timpuriu în Transilvania: o abordare Bayesiană”. Analele Banatului, SN, XXII (2014): 94, Tab.1.

${ }^{84}$ Comșa, „Cultura Boian”, 645, footnote 49; Dumitru Berciu, Zorile istoriei în Carpați şi la Dunăre. Bucureşti: Editura Ştiinţifică, 1966, 122; Marinescu-Bîlcu, Cultura Precucuteni, 133-134; Paul, Cultura, 29; Florin Draşovean, Cultura Vinča târzie ( faza C) în Banat. Timişoara: Editura Mirton, 1996, 95; Maxim, Neo-eneoliticul, 100; Gligor, Aşezarea, Pl. CXLVIII/1-12, CXLIX/1-6.

${ }^{85}$ Comşa, „Cultura Boian”, 645; Marinescu-Bîlcu, Cultura Precucuteni, 132, Fig. 26/4-6, 28/3, 29/1; Maxim, Neo-eneoliticul, 100.

${ }^{86}$ Marinescu-Bîlcu, Cultura Precucuteni, 134.

${ }^{87}$ Marinescu-Bîlcu, Cultura Precucuteni, 132; Maxim, Neo-eneoliticul, 100.

${ }^{88}$ Marinescu-Bîlcu, Cultura Precucuteni, Fig. 1.

${ }^{89}$ Paul, „Aşezarea neolitică”, 116; Fig. 5/1-4, 6/1-4, 9, 7/8-9; Marinescu-Bîlcu, Cultura Precucuteni, 133, footnote 143; Maxim, Neo-eneoliticul, 100.

${ }^{90}$ Marinescu-Bîlcu, Cultura Precucuteni, 133; Paul, Cultura, 54, footnote 14, 139; Luca, „Aspecte ale neoliticului”, 12-13.

${ }^{91}$ Luca et alii, Cercetări arheologice, 89-90, Pl. XXXV/1, Photo 28/2-6.

${ }^{92}$ Cavruc, Repertoriul, Pl. 5/1; Maxim, Neo-eneoliticul, 100; Lazarovici and Lazarovici, Arhitectura neoliticului, Fig. IVd. 1a/1-10; Gheorghe Lazarovici, Cornelia Magda Lazarovici, „Despre fazele A1 ale Grupelor Ariuşd şi Cucuteni”. Angvstia 14 (2010): Fig. 12.

${ }^{93}$ Marinescu-Bîlcu, Cultura Precucuteni, 133; Paul, Cultura, 53-54; Pl. XXII/1-9, 11-12; Maxim, Neo-eneoliticul, 100.

${ }^{94}$ Hortensia Dumitrescu, „Câteva probleme legate de cultura Petreşti”. Studii și Comunicări de Istorie Veche 17, 3 (1966): 442; Marinescu-Bîlcu, Cultura Precucuteni, 131; Gheorghe Lazarovici, Hortensia Dumitrescu, „Legăturile cronologice, culturale şi locul aspectului Tăualaş în cadrul 
Eresteghin, ${ }^{95}$ Feldioara, ${ }^{96}$ Fundătura, ${ }^{97}$ Ghirbom - În Fațăa, ${ }^{98}$ Goreni - Tormaş,, 9 Hălchiu, ${ }^{100}$ Iclod, ${ }^{101}$ Leț, ${ }^{102}$ Mihalț - Măticuta, ${ }^{103}$ Mintia - Gerhat, ${ }^{104}$ Noşlac, ${ }^{105}$ Oarda - Dublihan, ${ }^{106}$ Ocna Sibiului - Fața Vacilor, ${ }^{107}$ Olteni - Cariera de Nisip Site B, ${ }^{108}$ Orlat, ${ }^{109}$ Petreşti - Groapa Galbenă, ${ }^{110}$ Pianul de Jos - Podei, ${ }^{111}$ Răhău

culturii Vinča-Turdaş şi a neoliticului transilvan”. Acta Musei Napocensis XXII-XXIII (19851986): 15 .

95 Zoltan Székely, „Contribuții la studiul culturii Precucuteni în Valea Oltului”, in Culegere de studii şi cercetări, Braşov, I, 1967, 75-84, Fig. 4/5, Fig. 6/1, 6-8, Fig. 7/5, 8-9, 12, Fig. 8/1; Zoltan Székely, Lucrări alese, Sf. Gheorghe: Editura Sámán, 2012, 31-35; Marinescu-Bîlcu, Cultura Precucuteni, 132, Fig. 26/7, 28/5, 31/3-4, 34/1, 6, 8.

${ }^{96}$ Comşa, „Cultura Boian”, Fig. 5/2; Marinescu-Bîlcu, Cultura Precucuteni, 132.

${ }^{97}$ Maxim, Neo-eneoliticul, 100.

${ }^{98}$ Marinescu-Bîlcu, Cultura Precucuteni, p. 134, footnote 154; Ioan Al. Aldea, „Obiecte de cupru descoperite în așezarea neo-eneolitică de la Ghirbom (com. Berghin, jud. Alba)”. Apulum XVII (1979) 25; Paul, Cultura, 54, Pl. XXII/11, 13, 15.

${ }^{99}$ Zrínyi, „Contribuții”, Pl. I/8, VII/6; Lazarovici and Lazarovici, „Cultura Precucuteni”, Fig. 20.

${ }^{100}$ Marinescu-Bîlcu, Cultura Precucuteni, 132, footnote 134; Maxim, Neo-eneoliticul, 100.

${ }^{101}$ Gheorghe Lazarovici, Zoia Kalmar, „Şantierul arheologic Iclod. Campania 1985”. Apulum XXIV (1987): Fig. 10/16-20, Pl. IX/1-5; Gheorghe Lazarovici, Zoia Maxim, „Săpăturile arheologice de la Iclod (Campania 1988)”. Apulum XXVII-XXX (1990-1993): 54-57, fig. 26/6; Lazarovici and Lazarovici, „Despre fazele”, Fig. 13; Gheorghe Lazarovici, Cornelia Magda Lazarovici, "Corelations and observations regarding absolute and relative chronology based on Banat and Transylvania researches", in The Neolithic and Eneolithic in Southeast Europe. New Approaches to Dating and Cultural Dynamics in the $6^{\text {th }}$ to $4^{\text {th }}$ Millenium BC, Eds. W. Schier and Fl. Drașovean, Rahden/Westf., Verlag Marie Leidorf, 2014, [Prähistorische Archäologie in Södosteuropa, Band 28], Fig. 8; Lazarovici and Lazarovici, „Cultura Precucuteni”, Fig. 29/a; Maxim, Neoeneoliticul, 100; Colesniuc, Cultura Zau, Fig. 162a/3, 6, 8-9.

102 Eugenia Zaharia, “Augaben über die Boian-Giuleşti Kultur. Die Siedlung von Leț”. Dacia, NS, XI (1967): Abb. 6/1-2, 10/1, 11/3; Lazarovici and Lazarovici, „Cultura Precucuteni”, Fig. IVd. $1 b / 1-6$.

${ }^{103}$ Marinescu-Bîlcu, Cultura Precucuteni, 133; Maxim, Neo-eneoliticul, 100.

${ }^{104}$ Draşovean and Luca, „Considerații”, Fig. 3/4; Draşovean, Cultura Vinča, 95.

${ }^{105}$ Marinescu-Bîlcu, Cultura Precucuteni, 134.

${ }^{106}$ Rustoiu, „Așezarea de la Oarda”, P1. II/2.

107 Marinescu-Bîlcu, Cultura Precucuteni, 133, footnote 143; Iuliu Paul, „Sondajul arheologic de la Ocna Sibiului (r. Sibiu, reg. Braşov)”. Materiale și Cercetări Arheologice VIII (1962): Fig. 9/3-5; Paul, Cultura, Pl. XXII/10.

${ }^{108}$ Cavruc and Buzea, „Olteni”, 247; Buzea and Mateş „Modele miniaturale”, 42, Pl. III/2; Garvăn et alii, Precucuteni, 69-72/Fig. 38, 41-50; Buzea and Déak, „Ethno-Archaeological”, 613, Fig 5/4-5; Lazarovici and Lazarovici, „Cultura Precucuteni”, Fig. $2 c / 2$.

${ }^{109}$ Lazarovici and Lazarovici, „Cultura Precucuteni”, 58-63, Tab. 1.

${ }^{110}$ Marinescu-Bîlcu, Cultura Precucuteni, 133-134; Gheorghe Lazarovici, Zoia Kalmar, „Discuții pe marginea legăturilor cronologice şi culturale între grupul Iclod şi cultura Tisa”. Acta Musei Napocensis XIX (1982): Pl. IV/21, 23-24; Gligor, „Despre ceramica”, 233-238, Pl. I-III.

${ }^{111}$ Paul, „Aşezarea neo-eneolitică, 47-50, Pl. III/1-18; Marinescu-Bâlcu, Cultura Precucuteni, 
- Dealul Şipotelor, ${ }^{112}$ Sântimbru, ${ }^{113}$ Sf. Gheorghe, ${ }^{114}$ Tărtăria, ${ }^{115}$ Turdaş, ${ }^{116}$ Turia Biserica Reformatăa ${ }^{117}$ Țaga, ${ }^{118}$ Valea Nandrului - Dosul Mare, ${ }^{119}$ Zau de Câmpie - La Grădiniţăa, ${ }^{120}$

Certainly, the number of Precucuteni discoveries is higher. One must take into account than not all the materials included in the old collections of Transylvanian museums have been published, nor all the materials resulted from excavations. ${ }^{121}$ In other cases, such as the recently discovered material from Rupea (Braşov County), in our opinion, the pottery published as being Precucuteni does not present a typical decoration. ${ }^{122}$ Likewise, the spatial analysis of the finds (Pl. XI) reveals a concentration in two distinct areas, namely South-Eastern Transylvania and the middle Mureş basin.

\section{Conclusions}

The evolution and the relation of the bearers of Precucuteni culture with the neighbouring contemporary civilisations from either side of the Carpathians are far from being resolved. Recently, E. Ursu proposed the use of the term 'Precucuteni chronological horizon' for the Precucuteni-Ariușd-Cucuteni/ Tripolie cultural complex, because we cannot speak of a Precucuteni culture from a historical point of view, but more of a distinctive chronological horizon

129, 133; Maxim, Neo-eneoliticul, 100; Bem, Sistemul, Fig. 67/6-7, 97/1-2; Lazarovici and Lazarovici, „Cultura Precucuteni”, Fig. 17a/7, 17c/9-10.

112 Unpublished material held by the National Museum of Unification in Alba Iulia, discovered from the rescue research (2012) occasioned by the construction of the Deva - Sibiu highway.

${ }^{113}$ Marinescu-Bîlcu, Cultura Precucuteni, Fig. 1.

114 Zaharia, "Augaben”, 34, footnotes 83, 85, Abb. 13/3; Marinescu-Bîlcu, Cultura Precucuteni, 132, Fig. 31/1-2, 32/9; Buzea and Mateş „Modele miniaturale”, 43.

115 Marinescu-Bîlcu, Cultura Precucuteni, 134, footnote 150; Nicolae Vlassa, Neoliticul Transilvaniei, Cluj-Napoca, 1976 [Bibliotheca Musei Napocensis, III], 29-30.

${ }^{116}$ Marton Roska, A Torma Zsófia-Gyüjtemény. Az Erdély nemzeti múzeum éren-és régiségtárában, Kolozsvár, 1941, Tafel CXV/1-28; Luca, „Relațiile culturale”, Pl. I/5, II/1; Luca, Așezări neolitice, 68, Fig. 33/2, 36/5-8; Maxim, Neo-eneoliticul, 100; Colesniuc, Cultura Zau, fig. 160.

${ }^{117}$ Maxim, Neo-eneoliticul, 98.

${ }^{118}$ Lazarovici and Lazarovici, Arhitectura neoliticului 2006, Fig. IVd. 27; Lazarovici and Lazarovici, „Cultura Precucuteni”, Fig. 32/1-4.

${ }^{119}$ Luca and Roman, „Cercetări de suprafață”, Pl. XVII/7.

${ }^{120}$ Gheorghe Lazarovici, “The main problems of the cultural complex CCTLNI”. Analele Banatului, SN VII-VIII (1999-2000): 43-44.

${ }^{121}$ Sabin Adrian Luca, Tărtăria rediviva. Alba Iulia, Editura Altip, 2016 [Bibliotheca Brukenthal, LXXI], 24.

122 Silviu Gridan, „Un nou punct arheologic neolitic în sud-estul Transilvaniei, oraşul Rupea (jud. Braşov)", in ArheoVest, II/1, In Honorem Gheorghe Lazarovici. Interdisciplinaritate in Arheologie, Timişoara, 6 decembrie 2014, Eds. S. Forțiu, A. Cîntar, Szeged, JATEPress Kiadó, 2014, 246, Fig. 7. 
of the Precucuteni-Ariușd-Cucuteni/Tripolie cultural complex, with three evolution phases. ${ }^{123}$

Based on the technological and typological - stylistic study of the pottery from Alba Iulia-Lumea Nouă and Petreşti-Groapa Galbenă, we can say that the working hypothesis we proposed in the studies published in $2009^{124}$ (i.e. whether we can still speak only of Precucuteni imports in the Transylvanian settlement, and especially in the sites from the middle Mureş basin) remains as current as ever. At the present state of research, we do not believe that all these artefacts can still be interpreted as merely Precucuteni imports in Transylvanian settlements. The lack of habitation levels or archaeological features that we can attribute to the Precucuteni culture, especially in the middle Mureș basin, makes it likely that there was a 'fashion' of decorating pottery among the communities of the early Eneolithic; thus, the typical decoration was taken up following some initial exchanges and contacts. In our opinion, the inclusion of the 'wolf's teeth' and 'chessboard' decoration in the stylistic repertoire of the human communities living in the aforementioned geographic area, constitutes the main explanation of a large number of discoveries of this nature. We believe that especially among the large Neolithic settlements from the middle Mureș basin (Pl. XI) a significant percentage of the excised pottery had lost its initial ethno-cultural facet. For the moment, from the perspective of the pottery analysed in our study, a separation between the group of settlements from South-Eastern Transylvania and the sites from South-Western and central Transylvania is taking shape.

\section{The Repertory of Precucuteni-Type Discoveries in}

\section{Transylvania (Pl. XI)}

1. Alba Iulia-Lumea Nouă (Alba County); 2. Bancu (Harghita County); 3. Bernadea (Mureş County); 4. Brăduț (Covasna County); 5. Bogatu Român (Sibiu County); 6. Caşolţ-Poiana în Pisc (Sibiu County); 7. Câlnic (Alba County); 8. Cerişor-Peştera Cauce (Hunedoara County); 9. Ciucsângeorgiu (Harghita County); 10. Daia Română-Părăuţ (Alba County); 11. Eresteghin (Covasna County); 12. Feldioara (Braşov County); 13. Fundătura (Cluj County); 14. Ghirbom-În Față (Alba County); 15. Hălchiu (Braşov County); 16. Iclod (Cluj County); 17. Leț (Covasna County); 18. Mihalț-Măticuta (Alba County); 19. Mintia-Gerhat (Hunedoara County); 20. Noşlac (Alba County); 21. Oarda-Dublihan (Alba County); 22. Ocna Sibiului-Fața Vacilor (jud. Sibiu); 23. Olteni-Cariera de nisip/Site B (Covasna County); 24. Orlat (Sibiu County); 25. Petreşti-Groapa Galbenă (Alba County); 26. Pianul de Jos-Podei (Alba County); 27. Răhău-Dealul Şipotelor (Alba County); 28. Sântimbru (Alba

${ }^{123}$ Constantin Emil Ursu, „Precucuteni-cultură sau orizont cronologic?”. Memoria Antiquitatis XXIX-XXX (2013-2014): 14.

${ }^{124}$ Gligor, „Despre ceramica”, 239-242; Gligor, Așezarea, 91-92. 
County); 29. Sf. Gheorghe (Covasna County); 30. Tărtăria (Alba County); 31. Deva-Tăualaş (Hunedoara County); 32. Turdaş (Hunedoara County); 33. Turia-Biserica Reformată (Covasna County); 34. Țaga (Cluj County); 35. Valea Nandrului-Dosul Mare (Hunedoara County); 36. Zau de Câmpie-La Grădiniţă (Mureş County); 37. Goreni-Tormaş (Mureş County).

\section{Rezumat}

Scopul articolului de faţă este analiza materialelor ceramice de factură Precucuteni descoperite în Transilvania, având în prim plan ceramica de la Alba Iulia-Lumea Nouă (Pl. I-III, IV/2, V/8, VIII, IX/1, 3, X/1-2) și Petreşti-Groapa Galbenă (Pl. IV/1, 3-11, V/1-7, 9, VI-VII, IX/2, 4). De la Lumea Nouă este prezentată în acest articol o statuetă antropomorfă, de sex feminin, aproape întreagă. Ca talie, piesa redată în ronde-bosse, se încadrează în categoria statuetelor cu bustul în poziție verticală, de mici dimensiuni (între 3-8 cm). Prin tehnica şi canoanele de modelare, statueta reprezintă cel mai probabil o piesă de import din mediul precucutenian.

La ceramica studiată, decorul se realizează în interiorul liniilor incizate paralele, prin utilizarea tehnicii exciziei, în motivul „dinţilor de lup” şi a „tablei de şah". Important de precizat este faptul că în săpăturile recente au fost descoperite piese ceramice arse în tehnica black-topped, precum și un fragment de castron carenat, cu carena rotunjită, tipice pentru grupul Foeni, care prezintă motivul exciziei în „dinţi de lup”.

În prezent, repertoriul descoperirilor Precucuteni în Transilvania numără nu mai puțin de 37 de puncte arheologice (Pl. XI). În stadiul actual al cercetărilor, nu credem că mai pot fi interpretate toate artefactele doar ca importuri Precucuteni în aşezările transilvănene. Lipsa unor niveluri de locuire sau a unor complexe arheologice pe care să le putem atribui precucutenienilor în așezările din bazinul Mureșului mijlociu mai ales - indică ca probabilă o „modă” de ornamentare a ceramicii pentru comunitățile de la începutul eneoliticului, astfel că decorul tipic a fost preluat în baza unor schimburi și contacte inițiale. Includerea în repertoriul stilistic propriu, de către comunitățile umane din arealul geografic menționat mai sus, a decorului „dinți de lup” și „tabla de șah” constituie, în opinia noastră, principala explicație pentru numărul mare de descoperiri de această factură. Cu precădere în marile așezări neolitice din bazinul Mureșului mijlociu, credem că un procentaj semnificativ din ceramica excizată și-a pierdut componenta etno-culturală inițială. Se conturează la momentul de față, din perspectiva analizei ceramicii care a făcut obiectul studiului nostru, o separare a grupului de așezări din S-E Transilvaniei de siturile din S-V şi centrul Transilvaniei.

Cuvinte cheie: Alba Iulia-Lumea Nouă, Petrești-Groapa Galbenă, Transilvania, statuetă antropomorfă Precucuteni, decor excizat „dinți de lup” și ,tablă de șah” de tip Precucuteni, importuri/producție locală. 

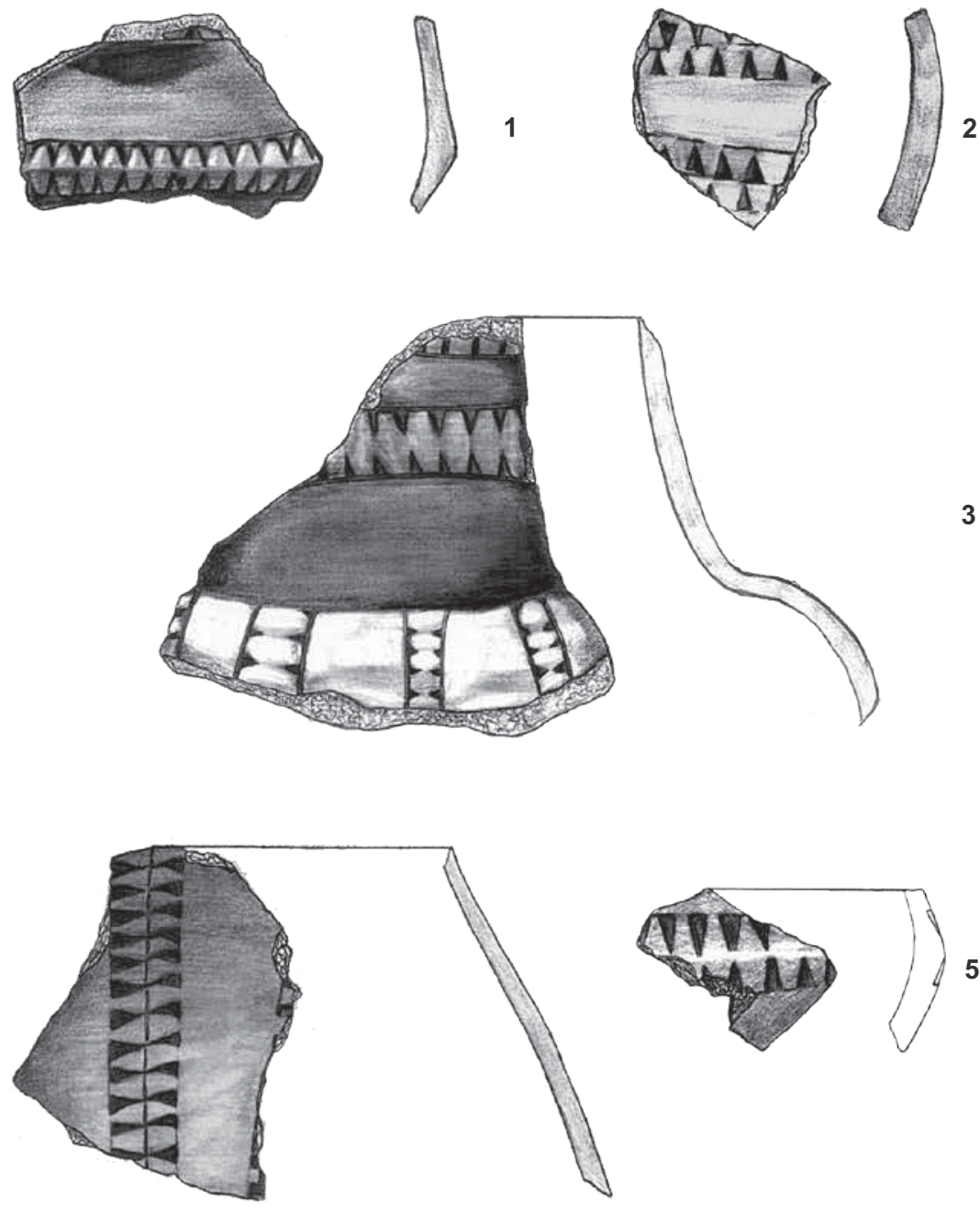

4

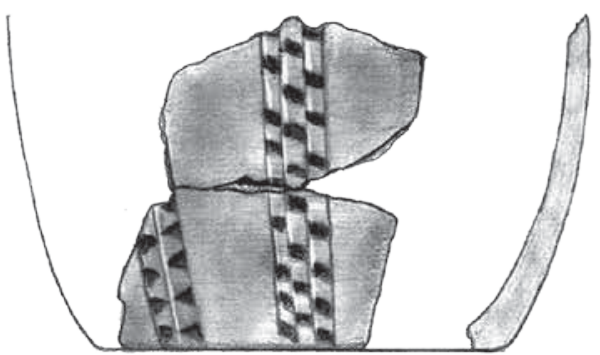

6

PI. I 
180 |PLURAL

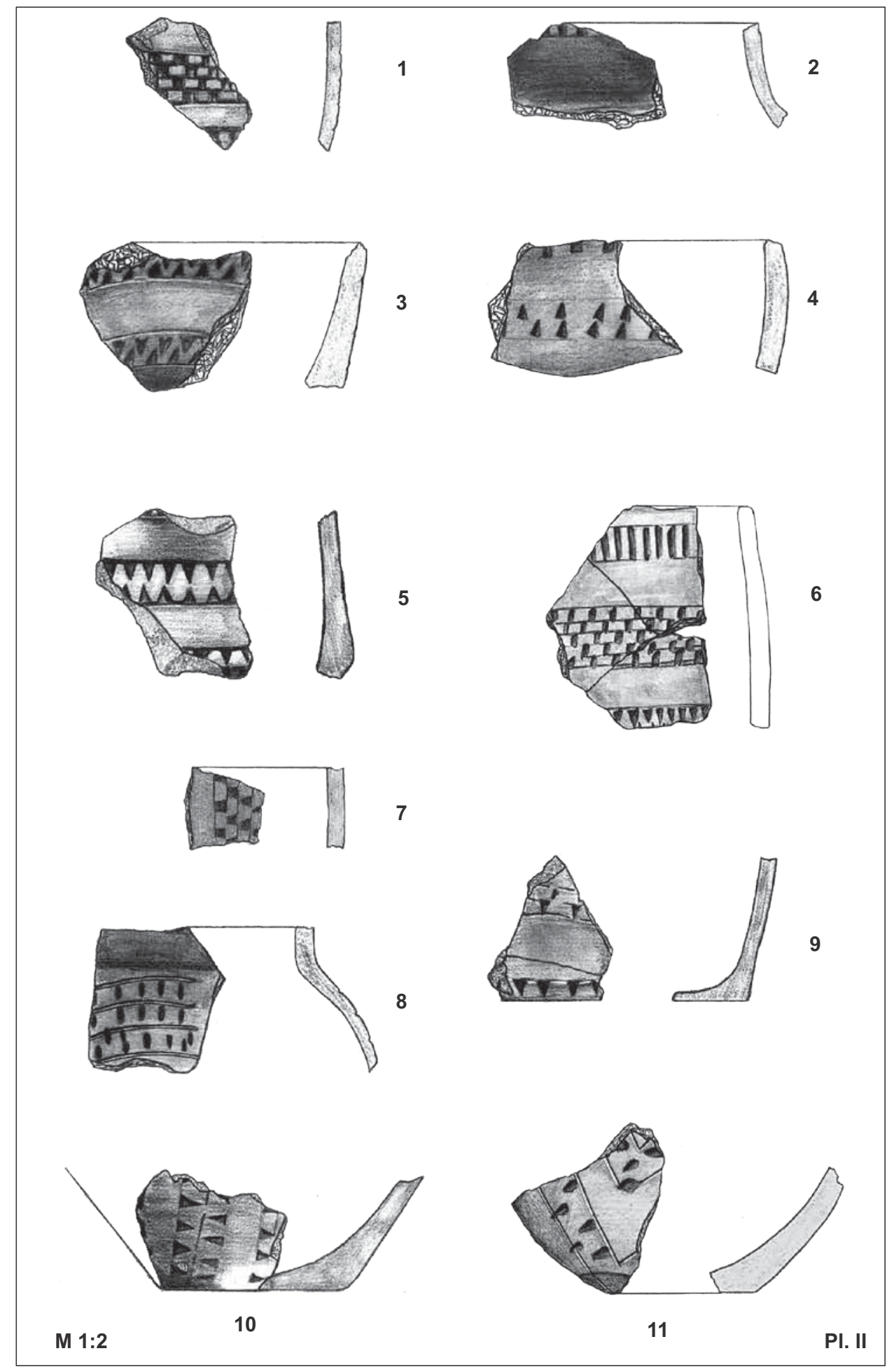




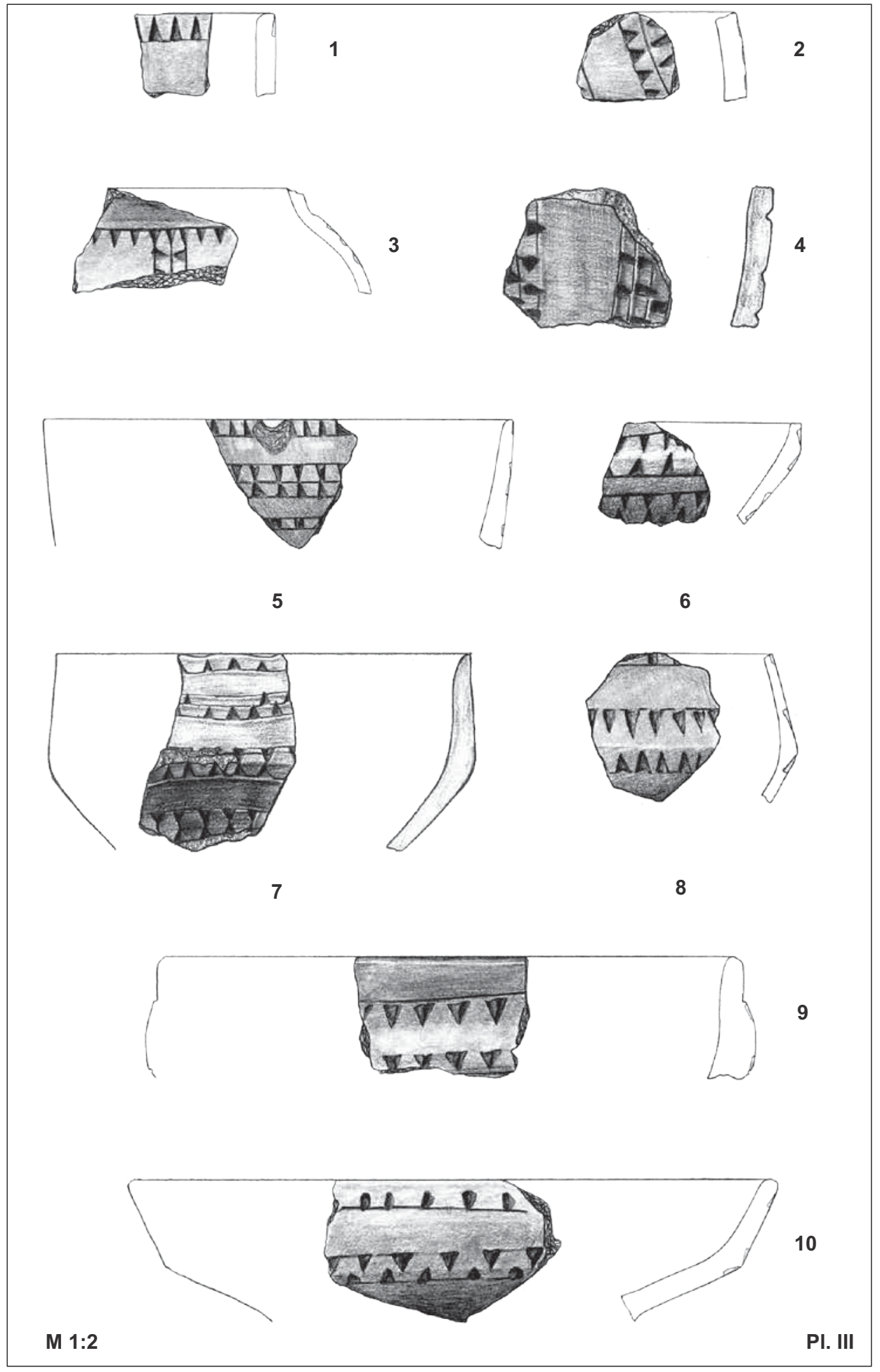


182 PLURAL

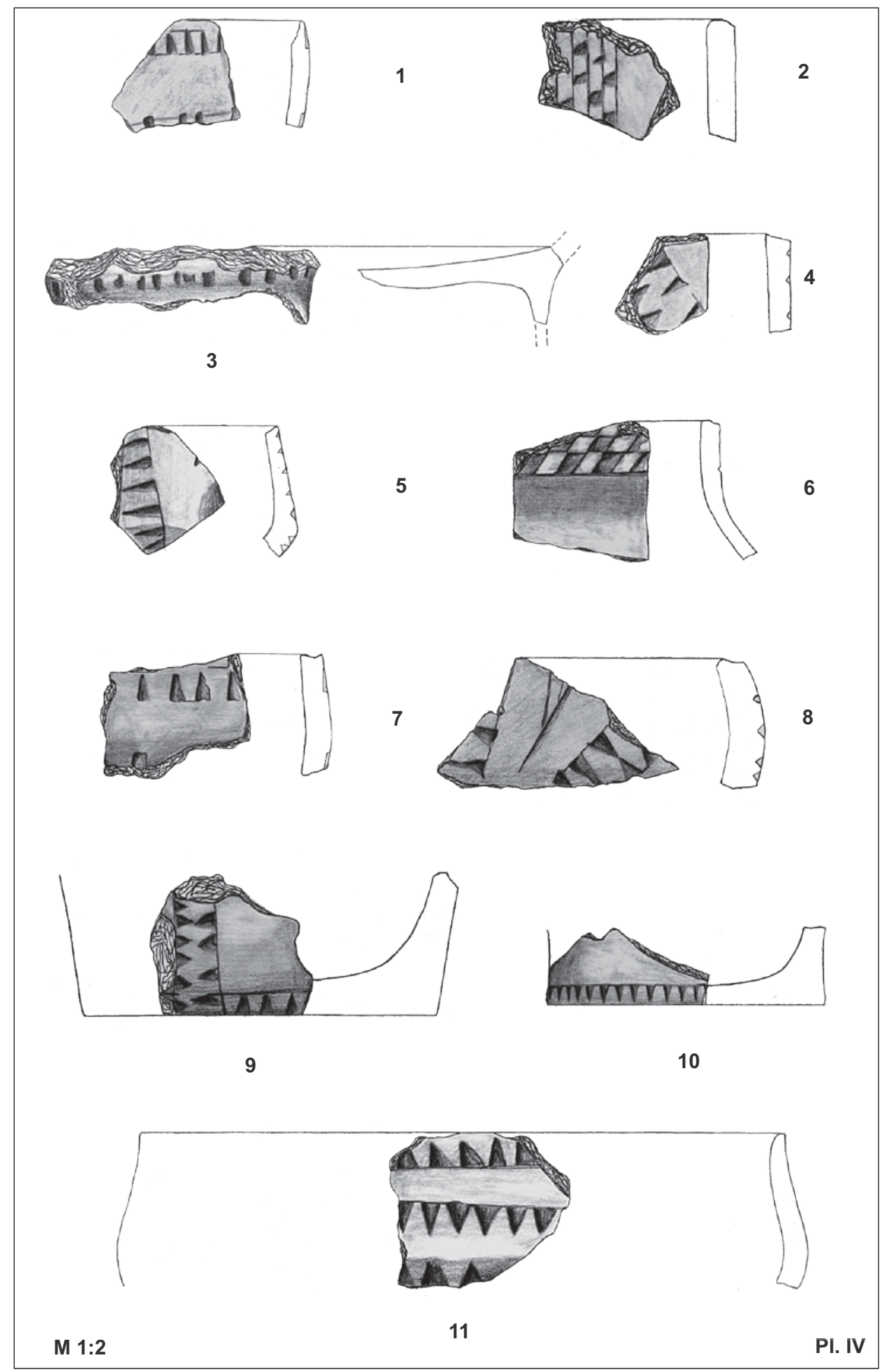



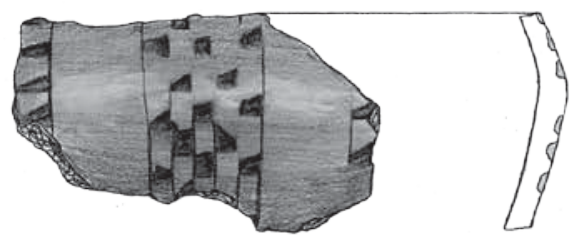

1
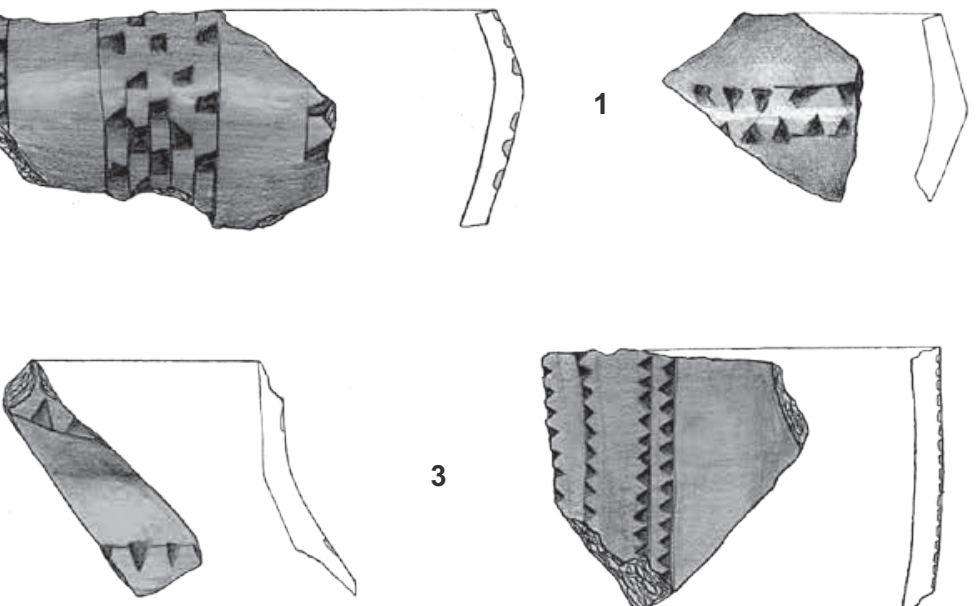

3

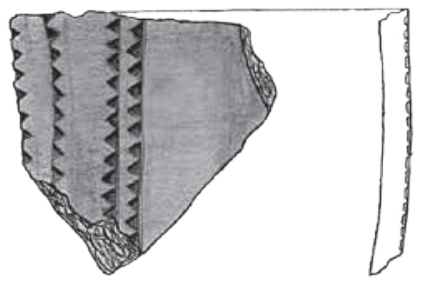

4

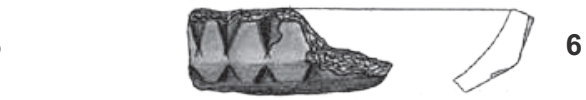

\section{5}
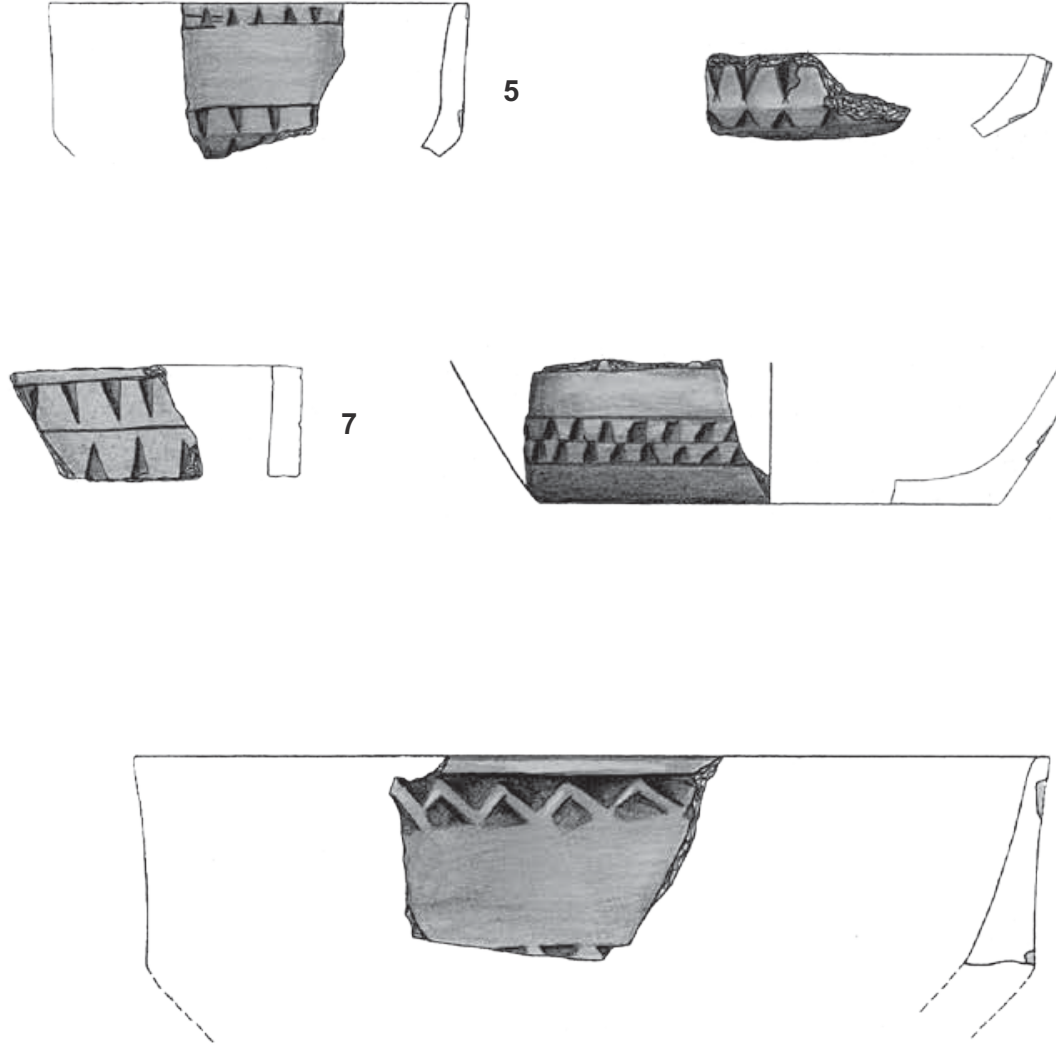

9 
184 PLURAL

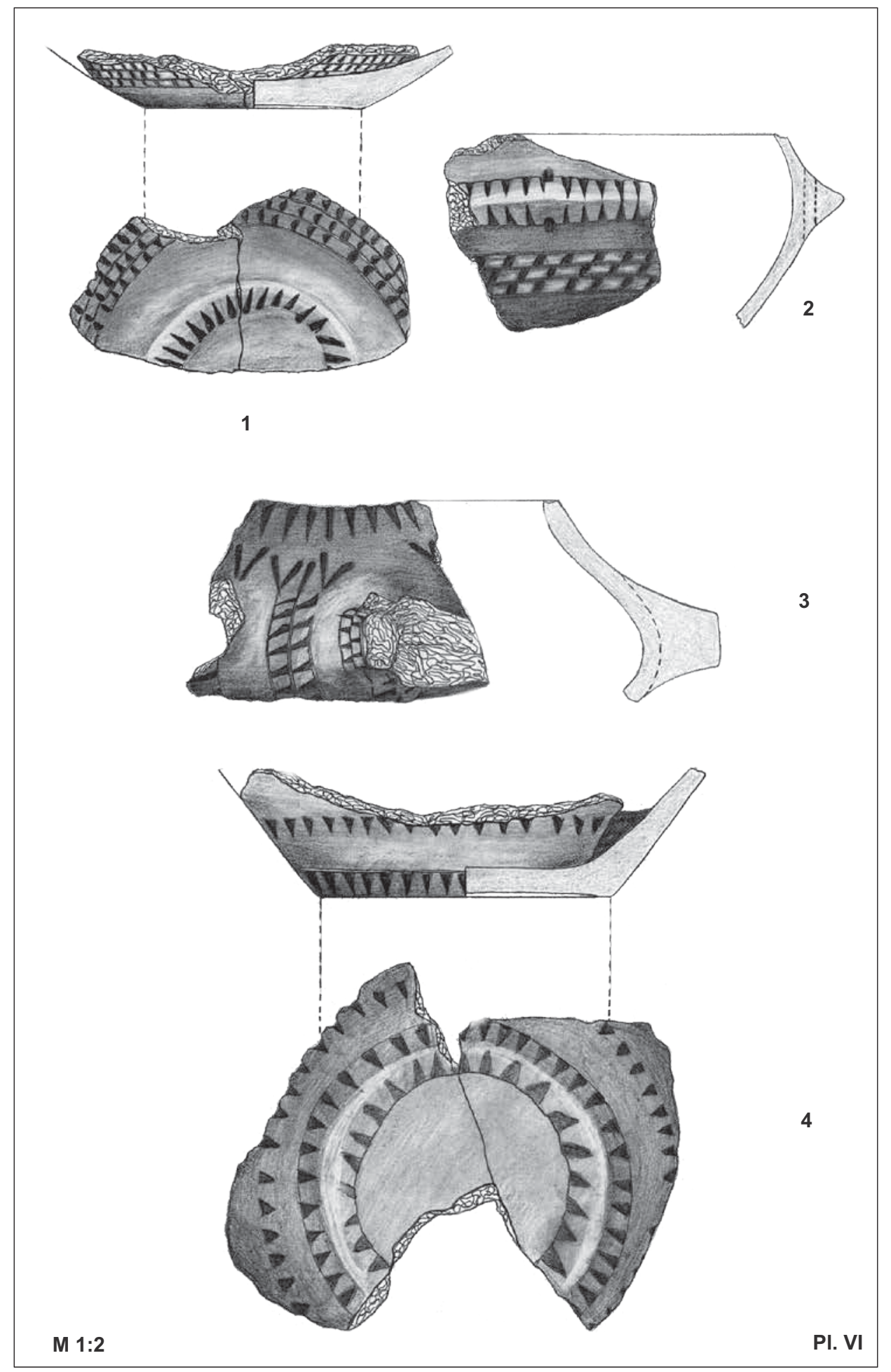




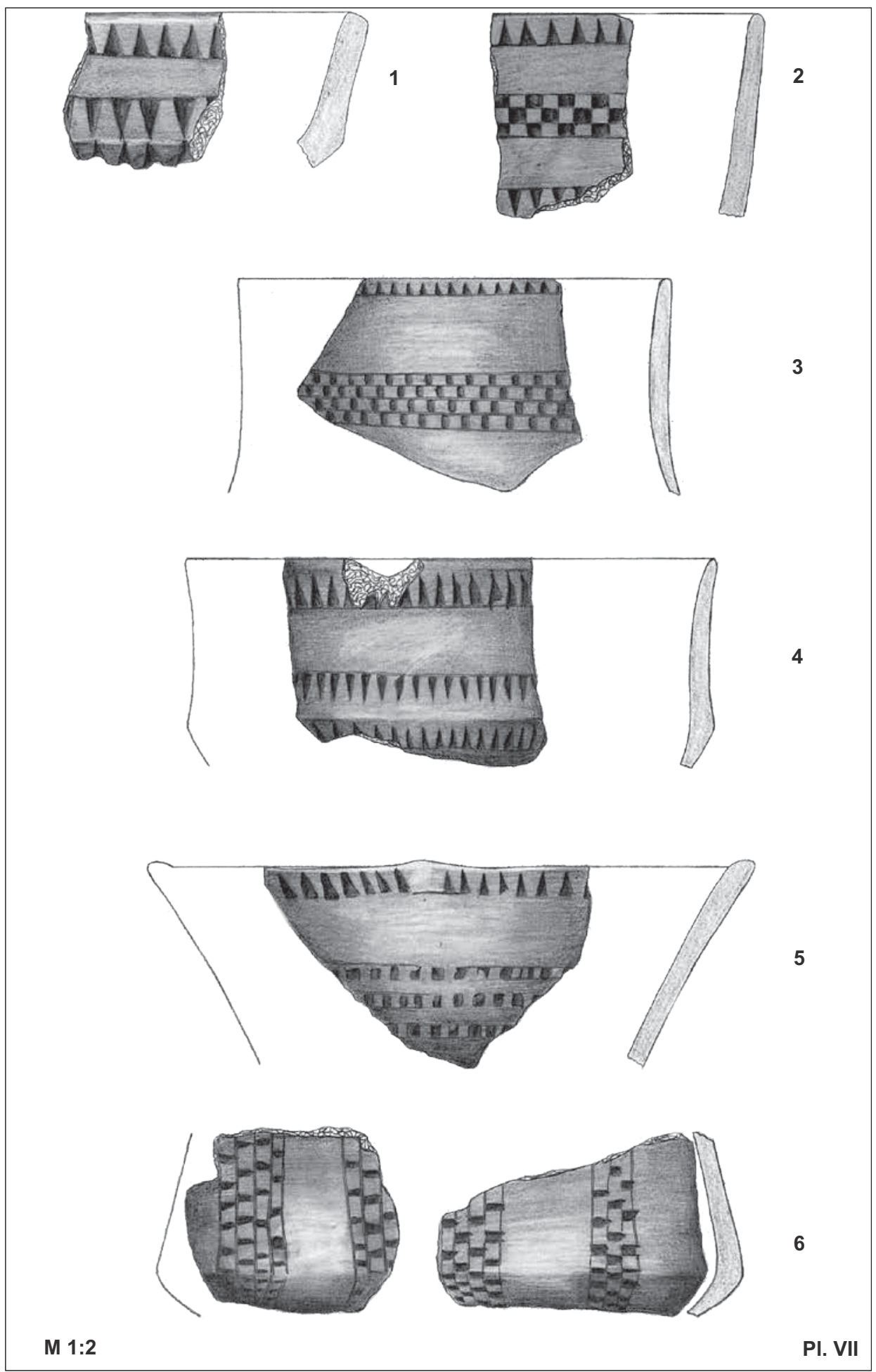


186 PLURAL

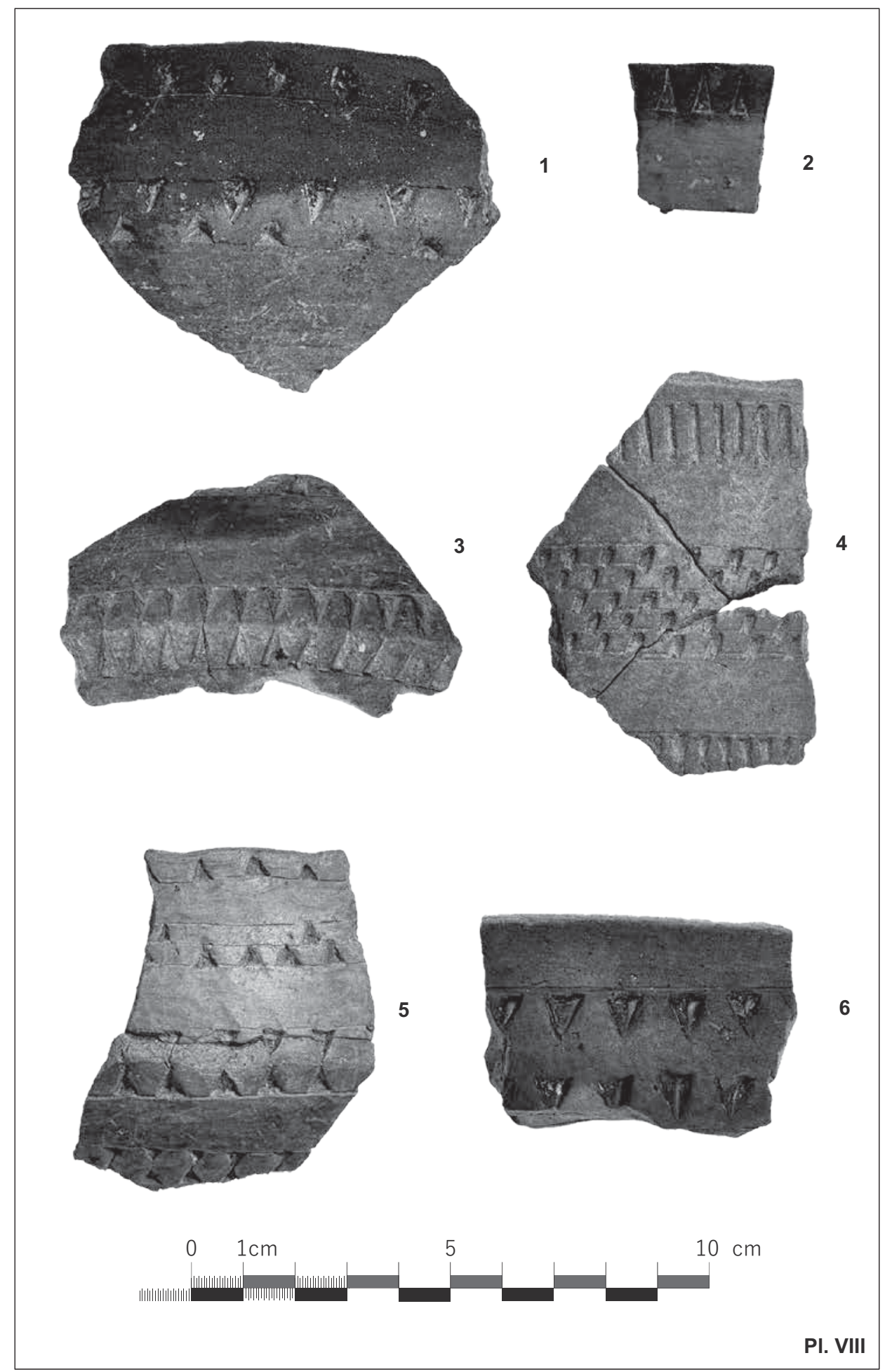




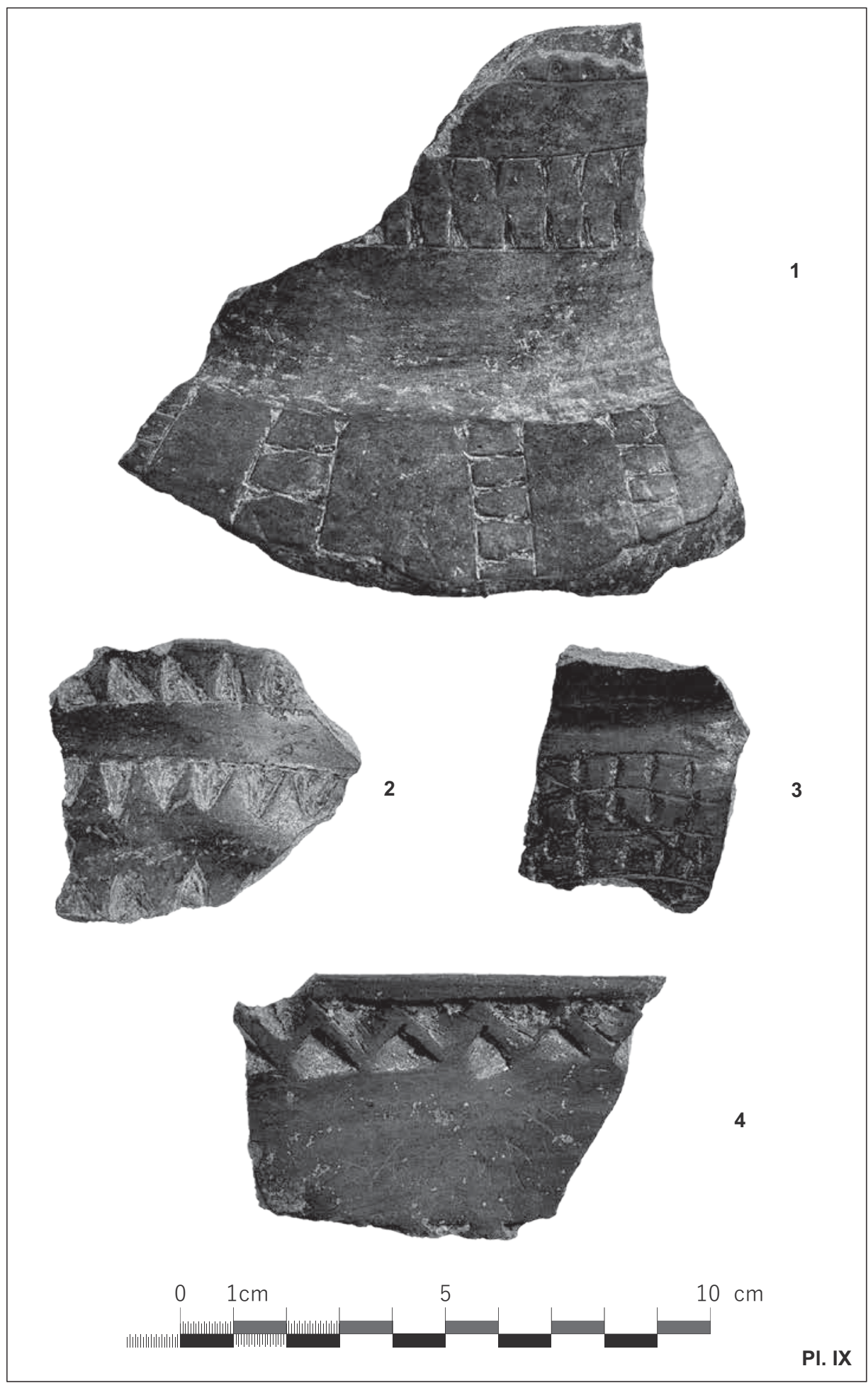




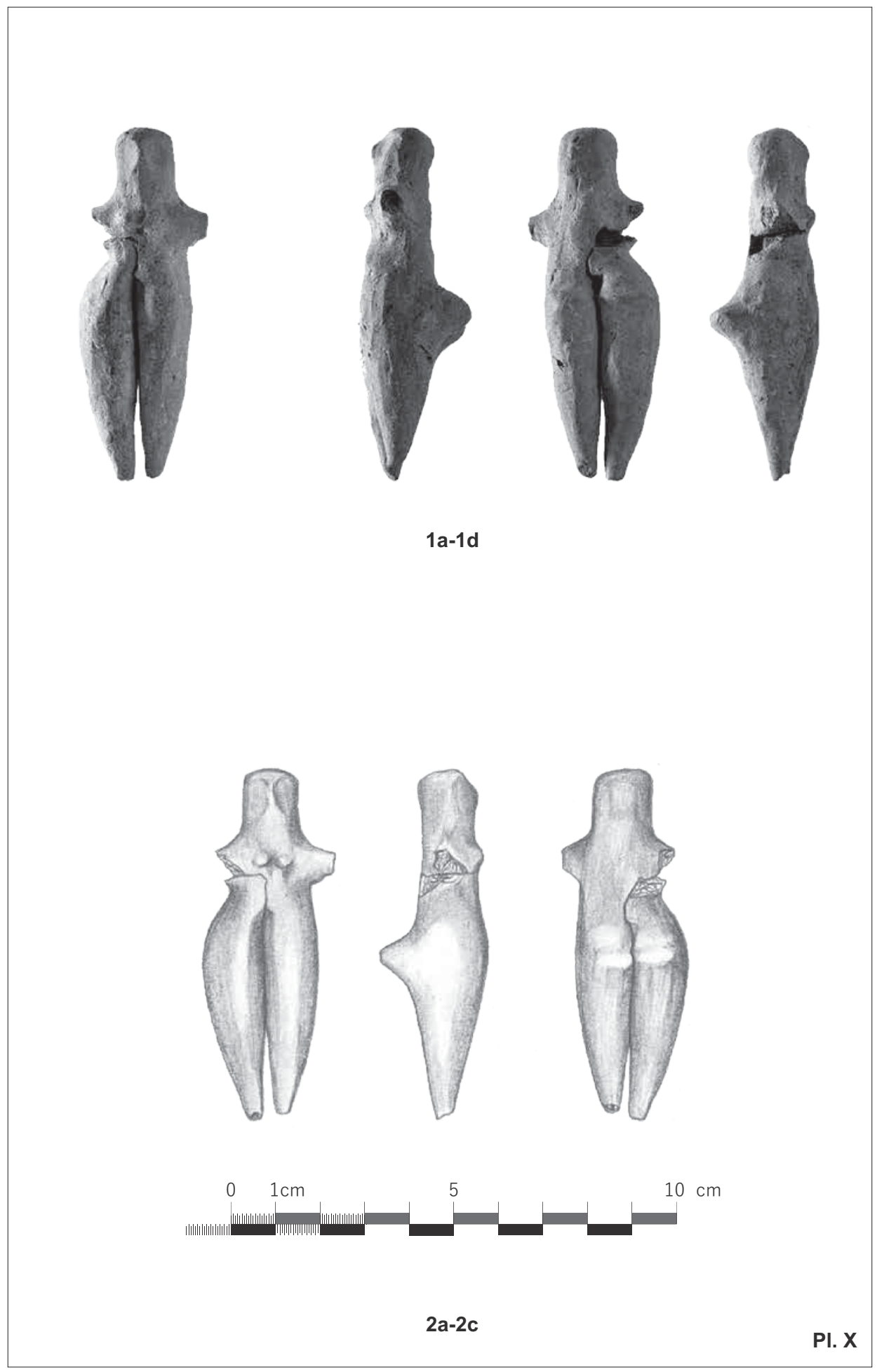




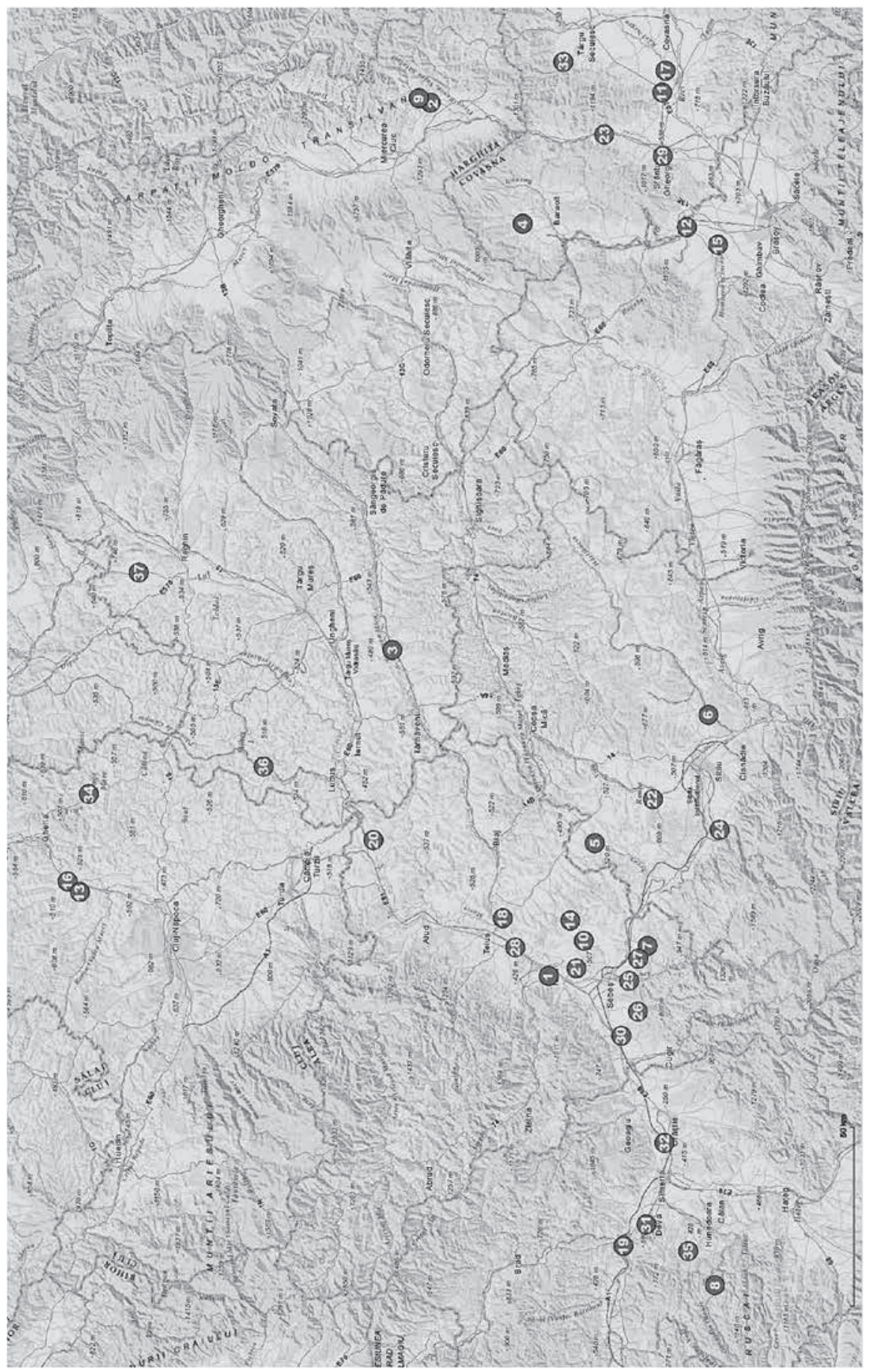

PI. XI 